\title{
Preclinical evidences toward the use of triterpenoid CDDO-Me for solid cancer prevention and treatment
}

\author{
Yan-Yang Wang ${ }^{*}$, Hong Zhe and Ren Zhao
}

\begin{abstract}
Solid cancer remains a major cause of death in the world. As limited treatment options are currently available to patients with solid cancer, novel preventive control and effective therapeutic approaches are considered to be reasonable and decisive measures to combat this disease. The plant-derived triterpenoids, commonly used for medicinal purposes in many Asian countries, poses various pharmacological properties. A large number of triterpenoids exhibit cytotoxicity against a variety of cancer cells, and cancer preventive, as well as anticancer efficacy in preclinical animal models. To improve antitumor activity, some synthetic triterpenoid derivatives have been synthesized, including cyano-3,12-dioxooleana-1,9(11)- dien-28-oic (CDDO), its methyl ester (CDDO-Me), and imidazolide (CDDO-Im) derivatives. In this review, we will critically examine the current preclinical evidences of cancer preventive and therapeutic activity about one of the synthetic triterpenoids, CDDO-Me. Both in vitro and in vivo effects of this agent and related molecular mechanisms are presented.
\end{abstract}

Keywords: Triterpenoid, CDDO-Me, Solid cancer, Prevention, Treatment, Mechanisms

\section{Introduction}

It has now become evident that cancer development underlies a collection of multiple genetic abnormalities through a multistep, mutagenic process $[1,2]$. The complexity of the genetic lesions and the variation of the derivative phenotypic changes of cancer cells indicate that multifunctional drugs capable of affecting cancer cells at various levels must be used for the treatment of these diseases [3,4]. With this background, agents like triterpenoids that can alter multiple dysregulated cellular pathways may have a significant potential for solid cancer prevention and treatment [5,6]. In this review, we will critically examine the current preclinical evidences of cancer preventive and therapeutic activity about one of the synthetic triterpenoids, C-28 methyl ester of 2-cyano-3,12dioxoolean-1,9-dien-28-oic acid (CDDO-Me). Both in vitro and in vivo effects of this agent and related molecular mechanisms are presented.

\footnotetext{
*Correspondence: shsyztd@sohu.com

Department of Radiation Oncology, General Hospital of Ningxia Medical University, No.804 Shengli Str, Yinchuan, Ningxia, China
}

\section{Introduction of CDDO-Me}

Triterpenoids are metabolites of isopentenyl pyrophosphate oligomers and represent the largest group of phytochemicals. It has been estimated that more than 20,000 triterpenoids exist in nature [7]. Triterpenoids are used medicinally in many Asian countries for their anti-inflammatory, analgesic, antipyretic, hepatoprotective, cardiotonic, sedative and tonic effects $[8,9]$. An increasing number of triterpenoids have been reported to exhibit cytotoxicity against a variety of cancer cells without manifesting any toxicity in normal cells. They also demonstrate antitumor efficacy in preclinical animal models of cancer $[4,10,11]$.

To improve antitumor activity, triterpenoid derivatives have been synthesized. In 1999, one such synthetic triterpenoid, 2-cyano-3,12-dioxoolean-1,9-dien-28-oic acid (CDDO), which has been found to be 100-500 fold more potent than any previous triterpenoids in suppressing inducible nitric oxide synthase and cyclooxygenase 2 (COX-2) - two inflammatory enzymes having important roles in the development of malignancy $[12,13]$, has been successfully developed [14]. In order to increase the potency of CDDO, various C-28 derivatives have been synthesized. CDDO-Me, one of the derivatives of CDDO, has shown the effects of preventing 
or treating cancer in a variety of studies [5]. The antiproliferative effect exerted by CDDO-Me in cancer cells seems to be more potent than that induced by either $\mathrm{C}-28$ imidazolide of CDDO (CDDO-Im) or CDDO itself [15]. CDDO-Me is one of the most potent activators of the Nuclear factor (erythroid-derived 2)-like 2 (Nrf2) pathway. Biological response to CDDO-Me is dependent on dose. Low concentrations (nanomolar) of CDDO-Me target kelch-like ECH-associated protein 1 (Keap1) and activate the Nrf2/ antioxidant responsive element (ARE) cytoprotective and anti-inflammatory response. As the concentration of CDDO-Me increases, it targets Actin-related protein 3 (Arp3) and other components of the cytoskeleton to inhibit cell proliferation, whereas even higher concentrations (micromolar) of CDDO-Me can selectively induce apoptosis in cancer cells by targeting a number of key regulatory proteins and pathways that are frequently constitutively activated or overexpressed in cancer cells [5].

\section{In vivo cancer preventive effects of CDDO-Me}

Anticarcinogenic activities of CDDO-Me have been established in both chemical carcinogenesis models and transgenic mouse models of various cancers (Table 1).
CDDO-Me is a potent inhibitor of lung carcinogenesis in $\mathrm{A} / \mathrm{J}$ mice. Liby et al. [16] looked at female $\mathrm{A} / \mathrm{J}$ mice treated with the mutagenic carcinogen vinyl carbamate, which induces adenocarcinoma of the lung in all animals within 16 weeks. If mice were fed either the CDDO-Me or the CDDO ethyl amide (CDDO-Ea), beginning 1 week after dosing with carcinogen, the number, size, and severity of lung carcinomas were markedly reduced. The triterpenoids CDDO-Ea and CDDO-Me reduced the average tumor burden (ATB) in the lungs $86 \%$ to $92 \%$, respectively, compared with the controls, and the rexinoid LG100268 reduced ATB by 50\%.

Liby et al. [17] also investigated whether the CDDO-Me and the rexinoid LG100268 could prevent the formation of estrogen receptor (ER)-negative mammary tumors in the mouse mammary tumor virus-neu transgenic model. Mice were fed control diet, CDDO-Me, LG100268, or the combination. CDDO-Me and LG100268 significantly delayed the development of ER-negative tumors, with a 14- and 24week delay, respectively, compared with the control group for the time required to reach $50 \%$ tumor incidence. The combination of CDDO-Me and LG100268 was significantly more potent than the individual drugs, as only one tumor

Table 1 In vivo solid cancer preventive effects of CDDO-Me

\begin{tabular}{|c|c|c|c|c|}
\hline Effects & Mechanisms & Dose/duration & Route & Reference \\
\hline $\begin{array}{l}\text { Decreased the average tumor burden of } \\
\text { vinyl carbamate-induced andenocarcinoma } \\
\text { in female } A \text { J mice }\end{array}$ & $\begin{array}{l}\text { Suppression of the ability of IFN- } \gamma \text { to induce } \\
\text { de novo formation of NO synthase; Induction } \\
\text { of HO-1; Suppression of phosphorylation of } \\
\text { STAT3 as well as induction of apoptosis }\end{array}$ & 60 mg/kg, 2 weeks & Diet & {$[16]$} \\
\hline $\begin{array}{l}\text { Prevented the formation of ER- negative } \\
\text { mammary tumors in the mouse mammary } \\
\text { tumor virus-neu transgenic model }\end{array}$ & $\begin{array}{l}\text { Inhibited constitutive STAT3 phosphorylation } \\
\text { and the degradation of IKBa }\end{array}$ & 60 mg/kg, 45 weeks & Diet & {$[17]$} \\
\hline $\begin{array}{l}\text { Increased survival of the KPC mice by } 3 \\
\text { to } 4 \text { weeks }\end{array}$ & $\begin{array}{l}\text { Interacted with both STAT3 and IKK to } \\
\text { decrease constitutive IL-6 secretion, inhibited } \\
\text { constitutive STAT3 phosphorylation, and } \\
\text { blocked the degradation of IKBa when } \\
\text { challenged with TNF-a }\end{array}$ & $\begin{array}{l}60 \mathrm{mg} / \mathrm{kg} \text { diet or } 15 \mathrm{mg} / \mathrm{kg} \text { body } \\
\text { weight. Beginning at } 4 \text { weeks of } \\
\text { age until detect tumor }\end{array}$ & Diet & {$[18]$} \\
\hline $\begin{array}{l}\text { Delayed ER-negative mammary } \\
\text { carcinogenesis in polyoma middle T Mice }\end{array}$ & $\begin{array}{l}\text { Inhibited cyclin D1 and decreased } \\
\text { phosphorylation of EGFR and STAT3 }\end{array}$ & 50 mg/kg, 4-8 weeks & Diet & {$[19]$} \\
\hline $\begin{array}{l}\text { Delayed tumor development in the } \\
\text { BRCA } 1 \text {-mutated mice by an average } \\
\text { of } 5.2 \text { weeks }\end{array}$ & $\begin{array}{l}\text { Interacted with ErbB2, decreased constitutive } \\
\text { phosphorylation of ErbB2, inhibited } \\
\text { proliferation, and induced G0/G1 arrest }\end{array}$ & $\begin{array}{l}50 \mathrm{mg} / \mathrm{kg} \text {. Beginning at } 12 \text { weeks } \\
\text { of age until detect tumor }\end{array}$ & Diet & {$[20]$} \\
\hline $\begin{array}{l}\text { Inhibited the progression of preneoplastic } \\
\text { lesions in the DLP and VP lobes to } \\
\text { adenocarcinoma in TRAMP mice }\end{array}$ & $\begin{array}{l}\text { Inhibited cell proliferation, reduced the } \\
\text { density of blood vessels and promoted } \\
\text { apoptosis in the prostatic tissue }\end{array}$ & $10 \mu \mathrm{mol} / \mathrm{kg} .20$ weeks & Oral gavage & {$[21]$} \\
\hline $\begin{array}{l}\text { Inhibited the progression of the } \\
\text { preneoplastic lesions to adenocarcinoma } \\
\text { in the DLP and VP lobes of TRAMP mice }\end{array}$ & $\begin{array}{l}\text { Inhibited the expression of prosurvival p-Akt } \\
\text { and NF-kB in the prostate }\end{array}$ & $\begin{array}{l}7.5 \mathrm{mg} / \mathrm{kg} / \text { day, } 5 \text { days/week. Early } \\
\text { intervention initiated at five weeks } \\
\text { of age for } 20 \text { weeks. Delayed } \\
\text { administration started at } 12 \text { week } \\
\text { of age for } 12 \text { weeks }\end{array}$ & Oral gavage & {$[22]$} \\
\hline $\begin{array}{l}\text { Inhibited the progression of preneoplastic } \\
\text { lesions to adenocarcinoma of the prostate } \\
\text { in TRAMP mice }\end{array}$ & $\begin{array}{l}\text { Decreased TERT and its regulatory proteins } \\
\text { in the prostate }\end{array}$ & $\begin{array}{l}15 \mu \mathrm{mol} / \mathrm{kg} / \text { day, } 5 \text { days/week, } \\
20 \text { weeks }\end{array}$ & Oral gavage & {$[23]$} \\
\hline
\end{tabular}

Akt: protein kinase B1; BRCA1:breast cancer-associated gene 1; DLP: dorsolateral prostate; EGFR: epidermal growth factor receptor; ER: estrogen receptor; ErbB2: human epidermal growth factor receptor 2; HO-1: heme oxygenase-1; IKBa, inhibitor of nuclear factor-KBa; IKK:IKB kinase; IL-6: interleukin-6; IFN- $\gamma$ : Interferon- $\gamma ;$ KPC; LSL-Kras ${ }^{\mathrm{G} 12 \mathrm{D} /+}$; LSL-Trp53 ${ }^{\mathrm{R} 127 \mathrm{H} /+} ; \mathrm{Pdx}-1-C r e ; ~ N F-K B$ : nuclear factor-KB; NO: nitric oxide; STAT3: transcription factor signal transducers and activators of transcription 3; TERT: telomerase reverse transcriptase TNF- $\alpha$ : tumor necrosis factor $\alpha$; TRAMP: transgenic adenocarcinoma of the mouse prostate model; VP: ventral prostate. 
was found in the combination group after 45 weeks on diet, at which time all control animals had tumors. The same group also found that CDDO-Me, LG100268, the combination of CDDO-Me and LG100268, and the combination of CDDO-Ea and LG100268, all significantly increased the survival of the LSL-Kras ${ }^{\mathrm{G} 12 \mathrm{D} /+}$; LSL-Trp53 ${ }^{\mathrm{R} 127 \mathrm{H} /+}$; Pdx-1-Cre (KPC) mouse pancreatic cancer model by 3 to 4 weeks [18].

Tran et al. [19] tested the activity of CDDO-Me in a relevant model of ER-negative breast cancer, the polyoma-middle $\mathrm{T}$ (PyMT), in which the oncoprotein drives carcinogenesis. Mice were fed CDDO-Me, starting at 4 weeks of age. CDDO-Me significantly increased the age of mice at onset of first tumor by an average of 4.3 weeks and overall survival by 5.2 weeks. The drug also inhibited the infiltration of tumor-associated macrophages into mammary glands of PyMT mice at 12 weeks of age and reduced levels of the chemokines CXCL12 and CCL2 in primary PyMT mammary tumor cells. Treatment with this multifunctional drug also inhibited secretion of matrix metalloproteinase- 9 in primary tumor cells from PyMT mice and decreased proliferation of these cells by inhibiting cyclin D1 and decreasing phosphorylation of epidermal growth factor receptor and signal transducer and activator of transcription 3 (STAT3).

In a mouse model in which deletion of the BRCA1 gene (breast cancer associated gene 1) is combined with a mutation in a single allele in the p53 tumor suppressor gene, CDDO-Me significantly delays tumor development [20]. Beginning at 12 weeks of age, $\mathrm{Brcal}^{\mathrm{Co} / \mathrm{Co}}$; MMTVCre; $53^{+/-}$mice were fed powdered control diet or diet containing CDDO-Me. CDDO-Me significantly delayed tumor development in the BRCA1-mutated mice by an average of 5.2 weeks. The authors also observed that levels of ErbB2, pErbB2, and cyclin D1 increased in a timedependent manner in the mammary glands in BRCA1deficient mice, and CDDO-Me inhibited the constitutive phosphorylation of ErbB2 in tumor tissues from these mice. In BRCA1-deficient cell lines, the triterpenoids directly interacted with ErbB2, decreased constitutive phosphorylation of ErbB2, inhibited proliferation, and induced G0/G1 arrest. These results suggest that CDDO-Me has the potential to prevent BRCA1-mutated breast cancer.

Deeb et al. reported that administration of CDDO-Me to transgenic adenocarcinoma of the mouse prostate (TRAMP) mice resulted in inhibition of progression of preneoplastic lesions (low and high-grade prostate intraepithelial neoplasms, PINs) to adenocarcinoma of the prostate in more than $70 \%$ of the mice without noticeable toxicity $[21,22]$. Subsequently, the same group also found that treatment with CDDO-Me inhibited metastasis of cancer to lung, liver, kidney and pelvic lymph nodes. The response to CDDO-Me in TRAMP mice was associated with reduction in proteins that regulate production and phosphorylation of telomerase reverse transcriptase (TERT) [23].

\section{In vitro and in vivo anticancer effects of CDDO-me}

In addition to its efficacy for prevention of cancer, CDDO-Me has been used to treat established tumors in experimental models (Table 2).

\section{In vitro studies \\ Targeting nuclear factor kappa B (NF-KB) pathway}

The NF- $\boldsymbol{k}$ B pathway is an important target of the CDDOme. NF- $\kappa \mathrm{B}$ activates a number of genes that promote inflammation, proliferation, and survival, and because it regulates the inflammatory microenvironment, this pathway can promote tumorigenesis [24,25]. Deeb et al. [26] investigated the response of hormone-sensitive (LNCaP) and hormone-refractory (PC-3 and DU145) human prostate cancer cell lines to CDDO-Me. Their results demonstrated that CDDO-Me could inhibit the growth of prostate cancer cells. Detailed analysis of the antitumor activity of CDDO-Me showed that it induced apoptosis in LNCaP and PC-3 cells through activation of caspases 3, 8 and 9, disruption of mitochondrial integrity, and inhibition of anti-apoptotic B-cell lymphoma 2 (Bcl-2), B-cell lymphoma extra large (Bcl-xL) and X-linked inhibitor of apoptosis protein (XIAP). Furthermore, induction of apoptosis was associated with inhibition of the NF- $\kappa$ B signaling pathway.

\section{Targeting phosphoinositide 3-kinase/ protein kinase B1/} mammalian target of rapamycin (PI3K/Akt/mTOR) pathway Although the activation of the PI3K/Akt/mTOR pathway may be beneficial in normal retinal epithelial cells or in neurons to enhance survival, this pathway is often overexpressed or activated in cancer cells [27]. Numerous inhibitors of this pathway are being evaluated in clinical trials for the treatment of cancer [28,29]. Deeb et al. [30] determined the antitumor activity and the mechanism of action of CDDO-Me for human prostate cancer cells. CDDO-Me inhibited the growth and induced apoptosis in PC-3 and C4-2 cells at extremely low concentrations. The antitumor activity of CDDO-Me was associated with the inhibition of $\mathrm{p}-\mathrm{Akt}, \mathrm{mTOR}$ and NF- $\mathrm{kB}$ signaling proteins and their downstream targets. Silencing of Akt sensitized the PC-3 cells to CDDO-Me, whereas overexpression of Akt induced resistance to CDDO-Me. Targeted silencing of Akt showed that Akt did not regulate mTOR activation in PC-3 cells, but targeted silencing of mTOR sensitized PC-3 cells to CDDO-Me mediated growth inhibition. These data identified Akt and mTOR as molecular targets of CDDO-Me in prostate cancer cells. In the subsequent study [31], the same group also found that CDDO-Me induced reactive oxygen species (ROS) generation. The inhibition of ROS generation by $\mathrm{N}$-acetylcysteine (NAC) or by overexpression of antioxidant enzymes glutathione peroxidase (GPx) and superoxide dismutase-1 (SOD-1) prevented CDDO-Me-induced apoptosis. NAC also prevented the inhibition of constitutively active Akt, NF- $\mathrm{kB}$ and 
Table 2 In vitro anti-cancer effects of CDDO-Me on various solid cancer cells

\begin{tabular}{|c|c|c|c|}
\hline Cellular effects & Mechanisms & Concentration & Reference \\
\hline $\begin{array}{l}\text { Inhibited proliferation and induced apoptosis by in } \\
\text { LNCaP and PC-3 prostate cancer cell lines }\end{array}$ & $\begin{array}{l}\text { Inhibited hTERT gene expression, hTERT telomerase activity } \\
\text { and a number of proteins that regulate hTERT } \\
\text { transcriptionally and posttranslationally }\end{array}$ & $0.063-5 \mu \mathrm{M}$ & [23] \\
\hline $\begin{array}{l}\text { Inhibited the growth of LNCaP, PC-3 and DU145 prostate } \\
\text { cancer cells }\end{array}$ & $\begin{array}{l}\text { Induced apoptosis through activation of caspases } 3,8 \text { and } \\
9 \text {, disruption of mitochondrial integrity, and inhibition of } \\
\text { anti-apoptotic Bcl-2, Bcl-xL and XIAP. Induction of } \\
\text { apoptosis was associated with the inhibition of } \\
\text { pro-survival Akt, mTOR, NF-kB signaling proteins }\end{array}$ & $1.25-20 \mu \mathrm{M}$ & {$[26]$} \\
\hline $\begin{array}{l}\text { Inhibited the growth and induced apoptosis in PC-3 and } \\
\text { c4-2 prostate cancer cells }\end{array}$ & $\begin{array}{l}\text { Inhibition of p-Akt, mTOR, and NF-kB signaling proteins } \\
\text { and their downstream targets such as p-Bad and p-Foxo3a } \\
\text { [Akt]; p-S6K1, p-elF-4E and p-4E-BP1 [mTOR]; and COX-2, } \\
\text { VEGF and cyclin D1[NF-kB] }\end{array}$ & $0.625-10 \mu \mathrm{M}$ & {$[30]$} \\
\hline $\begin{array}{l}\text { Inhibited the growth of both K-ras mutated and } \\
\text { wild-type K-ras pancreatic cancer cells }\end{array}$ & $\begin{array}{l}\text { Inhibited of prosurvival p-Akt, NF-KB and mTOR signaling } \\
\text { proteins and the downstream targets of Akt and mTOR, } \\
\text { such as p-Foxo3a [Akt] and p-S6K1, p-elF-4E and } \\
\text { p-4E-BP1 [mTOR] }\end{array}$ & $0.625-5 \mu \mathrm{M}$ & {$[32]$} \\
\hline Inhibited the growth of colorectal cancer cells & $\begin{array}{l}\text { Suppressed pro-survival Akt, NF-KB and mTOR signaling } \\
\text { proteins and NF-kB-regulated anti-apoptotic Bcl-2, BCl-xL, } \\
\text { Bad and survivin }\end{array}$ & $1.25-10 \mathrm{mM}$ & [34] \\
\hline $\begin{array}{l}\text { Inhibited the growth of human ovarian cancer cell lines } \\
\text { OVCAR-3, OVCAR-5 and SK-OV3 and ovarian } \\
\text { endometrioid adenocarcinoma cell line MDAH-2774 }\end{array}$ & Inhibition of Akt/ NF-KB /mTOR signaling pathway & $0.625-10 \mu \mathrm{M}$ & {$[36]$} \\
\hline $\begin{array}{l}\text { CDDO-Me caused the generation of ROS and } \\
\text { pre-treatment with NAC prevented the generation } \\
\text { of ROS in OVCAR- } 5 \text { and MDA } 2774 \text { ovarian cancer cells }\end{array}$ & $\begin{array}{l}\text { ROS played a pivotal role in the anti-proliferative and } \\
\text { apoptosis-inducing activity of CDDO-Me in ovarian } \\
\text { cancer cells }\end{array}$ & $1.25-10 \mu \mathrm{M}$ & {$[37]$} \\
\hline $\begin{array}{l}\text { Induced the apoptosis of glioblastoma [U87MG, U251MG] } \\
\text { and neuroblastoma [SK-N-MC] cell lines }\end{array}$ & $\begin{array}{l}\text { Inhibited the levels of anti-apoptotic and prosurvival p-Akt, } \\
\text { NF-kB and Notch1 signaling molecules }\end{array}$ & $2.5-10 \mu \mathrm{M}$ & {$[38]$} \\
\hline $\begin{array}{l}\text { Reversed the resistant of paclitaxel-resistant ovarian } \\
\text { cancer cell line OVCAR8TR and cisplatin-resistant ovarian } \\
\text { cancer cell line A2780cp70 }\end{array}$ & $\begin{array}{l}\text { Inhibited IL-6 secretion, STAT3 phosphorylation, STAT3 } \\
\text { nuclear translocation }\end{array}$ & $0.3 \mu \mathrm{M}$ & {$[42]$} \\
\hline $\begin{array}{l}\text { Reversed the resistant of MDR osteosarcoma cell lines } \\
\mathrm{KHOS}_{\mathrm{R} 2}, \mathrm{U}-2 \mathrm{OS} \mathrm{S}_{\mathrm{TR}}\end{array}$ & $\begin{array}{l}\text { Inhibited STAT3 phosphorylation, STAT3 nuclear } \\
\text { translocation and induced apoptosis }\end{array}$ & $0.1 ; 0.3 \mu \mathrm{M}$ & [43] \\
\hline $\begin{array}{l}\text { Activated the extrinsic DR-mediated apoptotic pathway } \\
\text { in human lung cancer cells }\end{array}$ & $\begin{array}{l}\text { Induced a JNK-dependent up-regulation of DR5 } \\
\text { expression, leading to activation of caspase-8 and } \\
\text { induction of apoptosis }\end{array}$ & $0.25-1 \mu \mathrm{M}$ & {$[47]$} \\
\hline $\begin{array}{l}\text { Induced JNK-dependent DR5 expression in human } \\
\text { lung cancer cells }\end{array}$ & $\begin{array}{l}\text { Depleted intracellular GSH, resulting in ER stress. } \\
\text { Subsequently, it activated JNK, leading to } \\
\text { CHOP-dependent DR5 up-regulation and apoptosis }\end{array}$ & $0.1-2 \mu \mathrm{M}$ & [48] \\
\hline $\begin{array}{l}\text { Induced apoptosis in human lung cancer cells A549 } \\
\text { and H157 }\end{array}$ & $\begin{array}{l}\text { Induced apoptosis through downregulation of c-FLIP } \\
\text { Enhanced TRAIL-induced apoptosis }\end{array}$ & $0.25 ; 0.5 ; 1 \mu \mathrm{M}$ & [49] \\
\hline $\begin{array}{l}\text { Inhibited proliferation and induced apoptosis in MiaPaCa-2 } \\
\text { and Panc-1 human pancreatic cancer cell lines }\end{array}$ & $\begin{array}{l}\text { Inhibited hTERT gene expression, hTERT telomerase } \\
\text { activity and a number of proteins that regulate } \\
\text { hTERT expression and activity }\end{array}$ & $1.25-5 \mu \mathrm{M}$ & [54] \\
\hline $\begin{array}{l}\text { Induced apoptosis in MiaPaCa-2 and Panc-1 human } \\
\text { pancreatic cancer cell lines }\end{array}$ & Generated ROS and inhibited the telomerase activity & $1.25 \mu \mathrm{M}$ & {$[55]$} \\
\hline $\begin{array}{l}\text { Inhibited MC38 colon carcinoma, Lewis lung carcinoma, } \\
\text { and EL-4 thymoma mouse tumor lines }\end{array}$ & $\begin{array}{l}\text { Blocked ROS production, decreased levels of peroxynitrite } \\
\text { and abrogated MDSC suppressive activity against } \\
\text { antigen-specific CD8+ T cells }\end{array}$ & $>1 \mu \mathrm{M}$ & {$[56]$} \\
\hline
\end{tabular}

Akt: protein kinase B1;Bad: Bcl-2-associated death promoter; Bcl-2:B-cell lymphoma 2; BCL-xL: B-cell lymphoma extra large; c-FLIP: cellular FLICE inhibitory protein; CHOP: CCAAT/enhancer binding protein homologous protein; COX-2: cyclooxygenase 2; DR:death receptor; ER: endoplasmic reticulum; GSH: glutathione; hTERT: human telomerase reverse transcriptase; JNK: c-Jun NH2-terminal kinase; MDR: multidrug resistant; MDSC: myeloid-derived suppressor cells; mTOR :mammalian target of rapamycin; NAC: N-acetylcysteine; NF-KB: nuclear factor-KB; ROS: reactive oxygen species; STAT3: transcription factor signal transducers and activators of transcription 3; TRAIL :TNF related apoptosis inducing ligand; VEGF: vascular endothelial growth factor; XIAP: X-linked inhibitor of apoptosis protein.

mTOR by CDDO-Me. The inhibition of PI3K/Akt/mTOR pathway may be a ROS dependent manner. Similar antitumor effect and mechanism of CDDO-Me also reported in pancreatic cancer cells [32,33], colorectal cancer cells $[34,35]$, ovarian cancer cells $[36,37]$, human glioblastoma and neuroblastoma cell lines [38]. 


\section{Targeting janus-activated kinase (JAK) /STAT pathway}

STATs are transcription factors known to contribute to cellular transformation, proliferation, survival, invasion, and metastasis, and STAT3 is constitutively activated in many types of cancers. After ligand binding to growth factor receptors, such as the interleukin 6 (IL-6) receptor, a JAK phosphorylates the receptor, allowing recruitment and phosphorylation of a STAT. STATs then dimerize, translocate to the nucleus, and induce transcription of numerous STAT targets, including cyclin D1, myc, and survivin proteins $[39,40]$. By directly interacting with Cys ${ }^{1077}$ on JAK1, CDDO-Me not only suppresses JAK1 phosphorylation but also inhibits its ability to phosphorylate STAT3 and induce STAT3 dimerization [41]. As both JAK and Src activation could induce STAT3 activation, inhibition of JAK2 or Src is another mechanism for CDDO-Me-mediated inhibition of STAT3 phosphorylation and nuclear translocation. In accordance with this mechanism, CDDO-Me can reverse the multi-drug resistant of ovarian cancer cells [42]. Similar anti-tumor effects and mechanism of CDDO-me are also found in osteosarcomas cancer cells [43].

\section{Targeting death receptor (DR) induced extrinsic apoptotic pathway}

It is well known that there are two major apoptotic pathways: the intrinsic mitochondria mediated pathway and the extrinsic DR induced pathway [44]. Several studies have demonstrated that CDDO-Me activates both intrinsic and extrinsic apoptotic pathways [45-47]. However, the DR5 related extrinsic apoptotic pathway has been extensively evaluated. Zou et al. showed that CDDO-Me induced DR5 up-regulation, which contributes to CDDO-Me induced apoptosis and enhancement of tumor necrosis factorrelated apoptosis-inducing ligand (TRAIL)-induced apoptosis in human non-small cell lung cancer (NSCLC) cells [47]. CDDO-Me depleted intracellular glutathione (GSH), resulting in endoplasmic reticulum stress. Subsequently, it activated c-Jun NH2-terminal kinase (JNK), leading to CCAAT/enhancer binding protein homologous protein (CHOP)-dependent DR5 up-regulation and apoptosis [48]. After that, they further showed that, in addition to DR5 induction, CDDO-Me down-regulated cellular FLICEinhibitory protein (c-FLIP) levels in human NSCLC cells though JNK-independent ubiquitin/proteasome-mediated degradation of c-FLIP. c-FLIP is a key regulatory protein that inhibits activation of the DR induced extrinsic apoptotic pathway. These studies provide compelling evidence for the involvement of the activation of the DR induced extrinsic apoptotic pathway in CDDO-Me-induced apoptosis in human NSCLC cells [49].

\section{Targeting telomere and/or telomerase}

Telomeres, the nucleoprotein structures present at the end of chromosomes, play a critical role in maintaining chromosome stability by preventing loss of telomeric repeats, end-to-end fusion and chromosomal rearrangement [50]. Telomeres shorten progressively during normal cell division due to a gradual loss of telomeric DNA sequence (TTAGGG) in each replication cycle $[51,52]$. When telomere length becomes critically short, it triggers replicative senescence or apoptosis. Maintaining telomere length is the function of telomerase (TERT), a ribonucleoprotein polymerase that adds the hexameric DNA repeats (TTAGGG) to the 3'flanking end of DNA strands in the telomere. Deregulated telomerase activity is associated with promotion of tumorigenesis and neoplastic growth of human cancers [53]. Deeb et al. [54] showed that inhibition of proliferation and induction of apoptosis in pancreatic cancer cells by CDDO-Me involved the inhibition of telomerase activity. CDDO-Me inhibited human TERT gene expression, human TERT protein and human TERT telomerase activity. Further, CDDO-Me also inhibited human TERT regulatory proteins such as c-Myc, specificity protein (Sp)1, NF-kB, p-STAT3 and p-Akt. Thus, targeting the telomere and/or telomerase with CDDO-Me is a promising strategy for the treatment of pancreatic cancer. Subsequently, they investigated the role of ROS in inhibition of telomerase by CDDO-Me. Treatment of MiaPaCa-2 and Panc-1 pancreatic cancer cell lines with CDDO-Me induced the production of hydrogen peroxide and superoxide anions and inhibited the telomerase activity. Pretreatment of cells with NAC, a general purpose antioxidant, or overexpression of GPx or SOD-1 blocked the telomerase inhibitory activity of CDDO-Me. Furthermore, blocking ROS generation also prevented the inhibition of TERT gene expression, protein production and expression of a number of human TERT-regulatory proteins by CDDO-Me. They concluded that inhibition of telomerase activity by CDDOMe was mediated through a ROS-dependent mechanism [55]. However, the titration effect and direct interaction between CDDO-Me and NAC should be considered when interpreting the results of these studies. Similar anti-tumor effect and mechanism of CDDO-Me also found in prostate cancer cells [23] and ovarian cancer cells [37].

\section{Targeting immune cells}

Nagaraj et al. [56] reported that CDDO-Me could block immune suppressive function of myeloid-derived suppressor cells (MDSC) and improve immune response of solid tumor. MDSC promote tumor angiogenesis, invasion and suppress $\mathrm{T}$ cell mediated immunosuppression of cancer cells $[57,58]$. They evaluated the effect of the CDDO-Me in MC38 colon carcinoma and Lewis lung carcinoma. They found that CDDO-Me completely abrogated immune suppressive activity of MDSC in vitro. CDDO-Me reduced ROS in MDSC but did not affect their viability or the levels of nitric oxide and arginase. CDDO-Me may favorably improve antitumor 
immune function, especially when combined with a cancer vaccine.

\section{In vivo studies}

Whether CDDO-Me inhibits tumor growth in vivo was examined in $\mathrm{PC}-3$ prostate cancer xenograft model system [30]. $2 \times 10^{6}$ PC-3 cells in $50 \mathrm{ml}$ of medium mixed with $50 \mathrm{ml}$ of matrigel were injected subcutaneous in the flank of $\mathrm{BALB} / \mathrm{c}$ nude mice. On day 8 , tumor dimensions were measured with a caliper and CDDO-Me treatment started. In the treatment group, mice were gavaged daily with $10 \mu \mathrm{mol} / \mathrm{kg}$ CDDO-Me in $0.1 \mathrm{ml}$ of vehicle consisting of cremaphor EL:DMSO:PBS (1:1:8), 5 days a week for 5 weeks. In the control group, mice were gavaged with vehicle without CDDO-Me. Tumors in the vehicle control group progressively increased in size over a period of 6 weeks and one mouse was terminated on day 39 because of large tumor size. In the CDDO-Me treatment group, after an initial increase in tumor size for about 2 weeks, tumors began to shrink and decreased in size. After 5 weeks of treatment with CDDO-Me, the average tumor size was significantly less than the size on the day treatment was started. On day 50, the experiment was terminated and tumors were harvested and weighed. Tumors of mice treated with CDDO-Me weighed significantly less than those of the untreated mice. These data demonstrated significant antitumor activity of CDDO-Me in vivo.

Jutooru et al. investigated the in vivo anticancer activity of CDDO-Me in an orthotopic model of pancreatic cancer in which L3.6pL cells were injected directly into the pancreas of 8 - to 12 -week-old male thymic nude mice. Treatment with CDDO-Me $(7.5 \mathrm{mg} / \mathrm{kg} /$ day $)$ was initiated 7 days after injection of the cells and continued for an additional 28 days. Treatment with CDDO-Me significantly decreased pancreatic tumor volume and weight compared with the vehicle control group. In addition, lysate from tumors treated with the vehicle or CDDO-Me were also analyzed by western blots, and there was a marked decrease in expression of $\mathrm{Sp} 1, \mathrm{Sp} 3$, and $\mathrm{Sp} 4$ proteins in tumors from mice treated with CDDO-Me compared with the control group. Moreover, expression of vascular endothelial growth factor (VEGF), cyclin D1, and survivin in tumors from CDDO-Me-treated mice were decreased compared with animals receiving vehicle control [59].

In an immunocompetent mouse model of breast cancer, chemoresistant 4 T1 cells, derived from a spontaneous mammary tumor, were injected back into BALB/c mice to study primary tumors as well as metastases. CDDOMe at $200 \mu \mathrm{g}$ per mouse was given intravenous at 2-day intervals. When treatment with CDDO-Me in liposomes was started 1 day after the injection of $4 \mathrm{~T} 1$ cells, the drug completely blocked tumor formation and metastasis. Tumor size was also significantly smaller in the mice treated with CDDO-Me than in the control group, even when treatment was delayed until 5 days after inoculation of the aggressive $4 \mathrm{~T} 1$ cells. Moreover, the population of mature dendritic cells in BALB/c mice with 4 T1 tumors decreases by two thirds compared with BALB/c mice without tumors, but CDDO-Me helped maintain the number of mature dendritic cells in this model. CDDO-Me not only inhibited the invasion of $4 \mathrm{~T} 1$ breast cancer cells into a matrix, but also eliminated metastasis to the lungs when these cells are injected into BALB/c mice [60].

MMTV-neu mice were used to test whether CDDO-Me and the rexinoid LG100268 prevent the formation of ER-negative mammary tumors, or either arrest the growth or cause regression of established tumors. Mice with tumors at least $4 \mathrm{~mm}$ in diameter were fed control diet, CDDO-Me (100 mg/kg diet), LG100268 (60 mg/kg diet), or the combination for 4 weeks. Treating established tumors with CDDO-Me arrested the growth of $86 \%$ of the tumors, and LG100268 induced tumor regression in $85 \%$ of tumors. CDDO-Me and LG100268 targeted different signaling pathways and cell types. CDDO-Me inhibited constitutive STAT3 phosphorylation and the degradation of IKBa in ER-negative breast cancer cells, whereas LG100268 blocked IKBa degradation and the release of IL-6 in RAW264.7 macrophage-like cells, inhibited the ability of endothelial cells to organize into networks, and blocked angiogenesis in vivo [17].

There are undoubtedly other targets and pathways that account for the effects of CDDO-Me on established cancers, but new mechanistic studies will require additional experiments and analysis in relevant animal models.

\section{Clinical trials}

Most of the experimental evidence favors further development of the triterpenoid CDDO-Me as a potential agent for prevention and treatment of cancer. Clinical trials should be carried out to test the potential efficacy of this drug in solid cancer treatment.

Nagaraj et al. [56] analyzed samples from 19 patients with pancreatic adenocarcinoma that were treated in the phase I clinical trial RTA 402-C-0702. Patients were treated intravenously with gemcitabine $\left(1,000 \mathrm{mg} / \mathrm{m}^{2}\right)$ weekly on days 1,8 , and 15 . CDDO-Me was administered orally once daily for 21 days. Nine patients received a dose of $150 \mathrm{mg} / \mathrm{d} ; 2$ patients, $200 \mathrm{mg} / \mathrm{d} ; 6$ patients, $250 \mathrm{mg} / \mathrm{d}$; and 2 patients, $300 \mathrm{mg} / \mathrm{d}$. No toxicity attributed to CDDO-Me was observed. Treatment of pancreatic cancer patients with CDDO-Me did not affect the number of MDSCs in peripheral blood, but significantly improved the immune response.

Hong et al. [61] established a phase I clinical trial which aimed to determine the dose-limiting toxicities (DLT), maximum tolerated dose (MTD), and appropriate dose for phase II studies; to characterize pharmacokinetic and pharmacodynamics parameters; and to assess antitumor 
activity. They found the DLT to be reversible grade 3 liver transaminase elevation. The MTD was established as $900 \mathrm{mg} / \mathrm{d}$. A complete tumor response occurred in a mantle cell lymphoma patient, and a partial response was observed in an anaplastic thyroid carcinoma patient. $\mathrm{NAD}(\mathrm{P}) \mathrm{H}$ dehydrogenase, quinone 1 (NQO1) mRNA levels increased in peripheral blood mononuclear cells, and NF- $\boldsymbol{\kappa}$ B and cyclin D1 levels decreased in tumor biopsies. They concluded that CDDO-Me was well tolerated with an MTD of $900 \mathrm{mg} / \mathrm{d}$. For the observed objective tumor responses, other synthetic triterpenoids were suggested for continued development in solid cancer treatment.

\section{Conclusions}

There has been substantial evidence supporting the preventive effect of CDDO-Me in a number of in vivo studies. There is also convincing evidence in laboratory studies and clinical trials in support of the antitumor effects of CDDO-Me in several cancers, with inhibition of tumor cell growth mainly by modulation of pathways that contribute to cell proliferation and apoptosis. Nevertheless, a considerable amount of work remains to be done, such as identification of novel target proteins and intercellular pathways in which they function, and development of selective end points and surrogate biomarkers for evaluating efficacy. Long standing epidemiological studies and well-designed clinical trials are also necessary.

In summary, the in vitro and in vivo data examined in this review strongly suggests that triterpenoid CDDO-Me is a promising candidate for the preventive and treatment of solid cancer.

\section{Competing interests}

The authors declare that they have no competing interests.

\section{Authors' contributions}

YYW wrote the manuscript. YYW, HZ, and RZ assisted with the revision of English grammar and style. All authors discussed the content and approved the final version of manuscript.

\section{Acknowledgement \\ We thank two anonymous reviewers for their invaluable comments and suggestions and Dr. David Leavesley at the Queensland University of Technology for his critical reading of the manuscript. This work was supported by Ningxia Medical University Research Grant (XM201317).}

Received: 7 September 2013 Accepted: 12 February 2014 Published: 20 February 2014

\section{References}

1. Hanahan D, Weinberg RA: The hallmarks of cancer. Cell 2000, 100:57-70.

2. Hanahan D, Weinberg RA: Hallmarks of cancer: the next generation. Cell 2011, 144:646-674.

3. Patlolla JM, Rao CV: Triterpenoids for cancer prevention and treatment: current status and future prospects. Curr Pharm Biotechnol 2012, 13:147-155.

4. Petronelli A, Pannitteri G, Testa U: Triterpenoids as new promising anticancer drugs. Anticancer Drugs 2009, 20:880-892.

5. Liby KT, Sporn MB: Synthetic oleanane triterpenoids: multifunctional drugs with a broad range of applications for prevention and treatment of chronic disease. Pharmacol Rev 2012, 64:972-1003.
6. Yadav VR, Prasad S, Sung B, Kannappan R, Aggarwal BB: Targeting inflammatory pathways by triterpenoids for prevention and treatment of cancer. Toxins (Basel) 2010, 2:2428-2466.

7. Liby KT, Yore MM, Sporn MB: Triterpenoids and rexinoids as multifunctional agents for the prevention and treatment of cancer. Nat Rev Cancer 2007, 7:357-369.

8. Ovesná Z, Vachálková A, Horváthová K, Tóthová D: Pentacyclic triterpenoic acids: new chemoprotective compounds. Minireview. Neoplasma 2004, 51:327-333

9. Bishayee A, Ahmed S, Brankov N, Perloff M: Triterpenoids as potential agents for the chemoprevention and therapy of breast cancer. Front Biosci 2011, 16:980-996.

10. Setzer WN, Setzer MC: Plant-derived triterpenoids as potential antineoplastic agents. Mini Rev Med Chem 2003, 3:540-556.

11. Laszczyk MN: Pentacyclic triterpenes of the lupane, oleanane and ursane group as tools in cancer therapy. Planta Med 2009, 75:1549-1560.

12. Murakami A, Ohigashi H: Targeting NOX, INOS and COX-2 in inflammatory cells: chemoprevention using food phytochemicals. Int J Cancer 2007, 121:2357-2363.

13. Kundu JK, Surh YJ: Inflammation: gearing the journey to cancer. Mutat Res 2008, 659:15-30.

14. Suh N, Wang Y, Honda T, Gribble GW, Dmitrovsky E, Hickey WF, Maue RA, Place AE, Porter DM, Spinella MJ, Williams CR, Wu G, Dannenberg AJ Flanders KC, Letterio JJ, Mangelsdorf DJ, Nathan CF, Nguyen L, Porter WW, Ren RF, Roberts AB, Roche NS, Subbaramaiah K, Sporn MB: A novel synthetic oleanane triterpenoid, 2-cyano-3,12-dioxoolean-1,9-dien-28-oic acid, with potent differentiating, antiproliferative, and anti-inflammatory activity. Cancer Res 1999, 59:336-341.

15. Deeb D, Gao X, Dulchavsky SA, Gautam SC: CDDO-Me inhibits proliferation, induces apoptosis, down-regulates Akt, mTOR, NF-kappaB and NF-kappaB-regulated antiapoptotic and proangiogenic proteins in TRAMP prostate cancer cells. J Exp Ther Oncol 2008, 7:31-39.

16. Liby K, Royce DB, Williams CR, Risingsong R, Yore MM, Honda T, Gribble GW Dmitrovsky E, Sporn TA, Sporn MB: The synthetic triterpenoids CDDO-methyl ester and CDDO-ethyl amide prevent lung cancer induced by vinyl carbamate in A/J mice. Cancer Res 2007, 67:2414-2419.

17. Liby K, Risingsong R, Royce DB, Williams CR, Yore MM, Honda T, Gribble GW, Lamph WW, Vannini N, Sogno I, Albini A, Sporn MB: Prevention and treatment of experimental estrogen receptor-negative mammary carcinogenesis by the synthetic triterpenoid CDDO-methyl Ester and the rexinoid LG100268. Clin Cancer Res 2008, 14:4556-4563.

18. Liby KT, Royce DB, Risingsong R, Williams CR, Maitra A, Hruban RH, Sporn $M B$ : Synthetic triterpenoids prolong survival in a transgenic mouse model of pancreatic cancer. Cancer PrevRes (Phila) 2010, 3:1427-1434.

19. Tran K, Risingsong R, Royce D, Williams CR, Sporn MB, Liby K: The synthetic triterpenoid CDDO-methyl ester delays estrogen receptor-negative mammary carcinogenesis in polyoma middle T mice. Cancer Prev Res (Phila) 2012, 5:726-734

20. Kim EH, Deng C, Sporn MB, Royce DB, Risingsong R, Williams CR, Liby KT: CDDO-methyl ester delays breast cancer development in BRCA1-mutated mice. Cancer Prev Res (Phila) 2012, 5:89-97.

21. Deeb D, Gao X, Liu Y, Jiang D, Divine GW, Arbab AS, Dulchavsky SA, Gautam SC: Synthetic triterpenoid CDDO prevents the progression and metastasis of prostate cancer in TRAMP mice by inhibiting survival signaling. Carcinogenesis 2011, 32:757-764.

22. Gao X, Deeb D, Liu Y, Arbab AS, Divine GW, Dulchavsky SA, Gautam SC: Prevention of prostate cancer with oleanane synthetic triterpenoid CDDO-Me in the TRAMP mouse model of prostate cancer. Cancers (Basel) 2011, 3:3353-3369.

23. Liu Y, Gao X, Deeb D, Arbab AS, Gautam SC: Telomerase reverse transcriptase (TERT) is a therapeutic target of oleanane triterpenoid CDDO-Me in prostate cancer. Molecules 2012, 17:14795-14809.

24. Karin M: NF-kappaB as a critical link between inflammation and cancer. Cold Spring Harb Perspect Biol 2009, 1:a000141.

25. Ben-Neriah Y, Karin M: Inflammation meets cancer, with NF-kB as the match maker. Nat Immunol 2011, 12:715-723.

26. Deeb D, Gao X, Dulchavsky SA, Gautam SC: CDDO-me induces apoptosis and inhibits Akt, mTOR and NF-kappaB signaling proteins in prostate cancer cells. Anticancer Res 2007, 27:3035-3044.

27. Engelman JA: Targeting PI3K signalling in cancer: opportunities, challenges and limitations. Nat Rev Cancer 2009, 9:550-562. 
28. Bunney TD, Katan M: Phosphoinositide signalling in cancer: beyond PI3K and PTEN. Nat Rev Cancer 2010, 10:342-352.

29. McNamara CR, Degterev A: Small-molecule inhibitors of the PI3K signaling network. Future Med Chem 2011, 3:549-565.

30. Deeb D, Gao X, Jiang H, Dulchavsky SA, Gautam SC: Oleanane triterpenoid CDDO-Me inhibits growth and induces apoptosis in prostate cancer cells by independently targeting pro-survival Akt and mTOR. Prostate 2009, 69:851-860.

31. Deeb D, Gao X, Jiang H, Janic B, Arbab AS, Rojanasakul Y, Dulchavsky SA, Gautam SC: Oleanane triterpenoid CDDO-Me inhibits growth and induces apoptosis in prostate cancer cells through a ROS-dependent mechanism. Biochem Pharmacol 2010, 79:350-360.

32. Deeb D, Gao X, Arbab AS, Barton K, Dulchavsky SA, Gautam SC: CDDO-Me: a novel synthetic triterpenoid for the treatment of pancreatic cancer. Cancers (Basel) 2010, 2:1779-1793.

33. Deeb D, Gao X, Liu YB, Gautam SC: Inhibition of cell proliferation and induction of apoptosis by CDDO-Me in pancreatic cancer cells is ROS-dependent. J Exp Ther Oncol 2012, 10:51-64.

34. Gao X, Deeb D, Hao J, Liu Y, Arbab AS, Dulchavsky SA, Gautam SC: Synthetic triterpenoids inhibit growth, induce apoptosis and suppress pro-survival Akt, mTOR and NF-\{kappa\}B signaling proteins in colorectal cancer cells. Anticancer Res 2010, 30:785-792.

35. Gao X, Deeb D, Liu P, Liu Y, Arbab-Ali S, Dulchavsky SA, Gautam SC: Role of reactive oxygen species (ROS) in CDDO-Me-mediated growth inhibition and apoptosis in colorectal cancer cells. J Exp Ther Oncol 2011, 9:119-127.

36. Gao X, Liu Y, Deeb D, Arbab AS, Guo AM, Dulchavsky SA, Gautam SC: Synthetic oleanane triterpenoid, CDDO-Me, induces apoptosis in ovarian cancer cells by inhibiting prosurvival AKT/NF-KB/mTOR signaling. Anticancer Res 2011, 31:3673-3681.

37. Gao X, Liu Y, Deeb D, Liu P, Liu A, Arbab AS, Gautam SC: ROS mediate proapoptotic and antisurvival activity of oleanane triterpenoid CDDO-Me in ovarian cancer cells. Anticancer Res 2013, 33:215-221.

38. Gao X, Deeb D, Jiang H, Liu Y, Dulchavsky SA, Gautam SC: Synthetic triterpenoids inhibit growth and induce apoptosis in human glioblastoma and neuroblastoma cells through inhibition of prosurvival Akt, NF-kappaB and Notch1 signaling. J Neurooncol 2007, 84:147-157.

39. Yu H, Pardoll D, Jove R: STATs in cancer inflammation and immunity: a leading role for STAT3. Nat Rev Cancer 2009, 9:798-809.

40. Grivennikov SI, Karin M: Dangerous liaisons: STAT3 and NF-kappaB collaboration and crosstalk in cancer. Cytokine Growth Factor Rev 2010, 21:11-19

41. Ahmad R, Raina D, Meyer C, Kufe D: Triterpenoid CDDO-methyl ester inhibits the Janus-activated kinase-1 (JAK1)- > signal transducer and activator of transcription-3 (STAT3) pathway by direct inhibition of JAK1 and STAT3. Cancer Res 2008, 68:2920-2926.

42. Duan Z, Ames RY, Ryan M, Hornicek FJ, Mankin H, Seiden MV: CDDO-Me, a synthetic triterpenoid, inhibits expression of IL-6 and Stat3 phosphorylation in multi-drug resistant ovarian cancer cells. Cancer Chemother Pharmacol 2009, 63:681-689.

43. Ryu K, Susa M, Choy E, Yang C, Hornicek FJ, Mankin HJ, Duan Z: Oleanane triterpenoid CDDO-Me induces apoptosis in multidrug resistant osteosarcoma cells through inhibition of Stat3 pathway. BMC Cancer 2010, 10:187.

44. Hengartner MO: The biochemistry of apoptosis. Nature 2000, 407:770-776.

45. Kim KB, Lotan R, Yue P, Sporn MB, Suh N, Gribble GW, Honda T, Wu GS, Hong WK, Sun SY: Identification of a novel synthetic triterpenoid, methyl-2-cyano-3,12-dioxooleana-1,9-dien-28-oate, that potently induces caspase-mediated apoptosis in human lung cancer cells. Mol Cancer Ther 2002, 1:177-184

46. Konopleva M, Tsao T, Ruvolo P, Stiouf I, Estrov Z, Leysath CE, Zhao S, Harris D, Chang S, Jackson CE, Munsell M, Suh N, Gribble G, Honda T, May WS, Sporn MB, Andreeff M: Novel triterpenoid CDDO-Me is a potent inducer of apoptosis and differentiation in acute myelogenous leukemia. Blood 2002, 99:326-335.

47. Zou W, Liu X, Yue P, Zhou Z, Sporn MB, Lotan R, Khuri FR, Sun SY: c-Jun $\mathrm{NH}$-terminal kinase-mediated up-regulation of death receptor 5 contributes to induction of apoptosis by the novel synthetic triterpenoid methyl-2-cyano-3,12-dioxooleana-1, 9-dien-28-oate in human lung cancer cells. Cancer Res 2004, 64:7570-7578.

48. Zou W, Yue P, Khuri FR, Sun SY: Coupling of endoplasmic reticulum stress to CDDO-Me-induced up-regulation of death receptor 5 via a CHOP-dependent mechanism involving JNK activation. Cancer Res 2008, 68:7484-7492.
49. Zou W, Chen S, Liu X, Yue P, Sporn MB, Khuri FR, Sun SY: c-FLIP downregulation contributes to apoptosis induction by the novel synthetic triterpenoid methyl-2-cyano-3, 12-dioxooleana-1, 9-dien-28-oate (CDDO-Me) in human lung cancer cells. Cancer Biol Ther 2007, 6:1614-1620.

50. Greider CW: Chromosome first aid. Cell 1991, 67:645-647.

51. Kim NW, Piatyszek MA, Prowse KR, Harley CB, West MD, Ho PL, Coviello GM, Wright WE, Weinrich SL, Shay JW: Specific association of human telomerase activity with immortal cells and cancer. Science 1994, 266:2011-2015.

52. Shay JW, Bacchetti S: A survey of telomerase activity in human cancer. Eur J Cancer 1997, 33:787-791.

53. Cech TR: Beginning to understand the end of the chromosome. Cell 2004, 116:273-279.

54. Deeb D, Gao X, Liu Y, Kim SH, Pindolia KR, Arbab AS, Gautam SC: Inhibition of cell proliferation and induction of apoptosis by oleanane triterpenoid (CDDO-Me) in pancreatic cancer cells is associated with the suppression of hTERT gene expression and its telomerase activity. Biochem Biophys Res Commun 2012, 422:561-567.

55. Deeb D, Gao X, Liu Y, Varma NR, Arbab AS, Gautam SC: Inhibition of telomerase activity by oleanane triterpenoid CDDO-Me in pancreatic cancer cells is ROS-dependent. Molecules 2013, 18:3250-3265.

56. Nagaraj S, Youn Jl, Weber H, Iclozan C, Lu L, Cotter MJ, Meyer C, Becerra CR, Fishman M, Antonia S, Sporn MB, Liby KT, Rawal B, Lee JH, Gabrilovich DI: Anti-inflammatory triterpenoid blocks immune suppressive function of MDSCs and improves immune response in cancer. Clin Cancer Res 2010, 16:1812-1823.

57. Ostrand-Rosenberg S: Myeloid-derived suppressor cells: more mechanisms for inhibiting antitumor immunity. Cancer Immunol Immunother 2010, 59:1593-1600.

58. Youn Jl, Gabrilovich DI: The biology of myeloid-derived suppressor cells: the blessing and the curse of morphological and functional heterogeneity. Eur J Immunol 2010, 40:2969-2975.

59. Jutooru I, Chadalapaka G, Abdelrahim M, Basha MR, Samudio I, Konopleva M, Andreeff M, Safe S: Methyl 2-cyano-3,12-dioxooleana-1,9-dien-28-oate decreases specificity protein transcription factors and inhibits pancreatic tumor growth: role of microRNA-27a. Mol Pharmacol 2010, 78:226-236.

60. Ling X, Konopleva M, Zeng Z, Ruvolo V, Stephens LC, Schober W, McQueen $T$, Dietrich M, Madden TL, Andreeff M: The novel triterpenoid C-28 methyl ester of 2-cyano-3, 12-dioxoolen-1, 9-dien-28-oic acid inhibits metastatic murine breast tumor growth through inactivation of STAT3 signaling Cancer Res 2007, 67:4210-4218.

61. Hong DS, Kurzrock R, Supko JG, He X, Naing A, Wheler J, Lawrence D, Eder JP, Meyer CJ, Ferguson DA, Mier J, Konopleva M, Konoplev S, Andreeff M, Kufe D, Lazarus H, Shapiro Gl, Dezube BJ: A phase I first-in-human trial of bardoxolone methyl in patients with advanced solid tumors and lymphomas. Clin Cancer Res 2012, 18:3396-3406.

doi:10.1186/1476-4598-13-30

Cite this article as: Wang et al:: Preclinical evidences toward the use of triterpenoid CDDO-Me for solid cancer prevention and treatment. Molecular Cancer 2014 13:30.

\section{Submit your next manuscript to BioMed Central and take full advantage of:}

- Convenient online submission

- Thorough peer review

- No space constraints or color figure charges

- Immediate publication on acceptance

- Inclusion in PubMed, CAS, Scopus and Google Scholar

- Research which is freely available for redistribution 